\title{
Speciation of Heavy Metals by Modified BCR Sequential Extraction in Soils Contaminated by Phosphogypsum in Sfax, Tunisia
}

\author{
Ahmed Wali ${ }^{1}$, Gilles Colinet ${ }^{2}$, Mohamed Ksibi ${ }^{1}$ \\ ${ }^{1}$ University of Sfax, National Engineering School of Sfax (ENIS), Laboratory of Water, Energy and Environment, \\ Sfax, Tunisia \\ ${ }^{2}$ Laboratory of Soil Science, Gembloux Agro-bio Technology University, Liege University, Gembloux, Belgium \\ Corresponding author: \\ K. Mohamed, Laboratory of Water, Energy and Environment, University of Sfax, ISBS B.P 1175, 3038 road of \\ Soukra km 3.5 Sfax Tunisia \\ E-mail: mohamed.ksibi@tunet.tn
}

\begin{abstract}
The accumulation of trace metals in soil is a serious environmental problem that creates a hazard when metals are transferred to water or plants. To understand the mobility and bioavailability of trace metals, the concentrations and distributions of trace metals must be established for different physical and chemical phases of the soil. We determined the concentrations of trace metals ( $\mathrm{Zn}, \mathrm{Pb}, \mathrm{Cu}, \mathrm{Cr}, \mathrm{Co}, \mathrm{Ni}, \mathrm{Mn}$, and $\mathrm{Fe}$ ) in soil using the sequential extraction method recommended by Community Bureau of Reference (BCR) and analysed chemical properties, such as the $\mathrm{pH}$, cation exchange capacity, total organic carbon, electrical conductivity, and calcium carbonate. Our results revealed higher concentrations of trace metals in topsoil samples $(0-20 \mathrm{~cm})$ than in subsoil samples $(20-40 \mathrm{~cm}$ and $40-60 \mathrm{~cm})$ for most metals at four sites. $\mathrm{Zn}$ in the topsoil was mostly associated with the non-resistant fraction at all sites. Approximately $60 \%$ more $\mathrm{Pb}$ was bound to the non-residual, exchangeable and reducible fractions at all sites, and soil depths. $\mathrm{Cr}, \mathrm{Cu}, \mathrm{Ni}$ and Fe were mainly in the residual fraction, whereas $\mathrm{Mn}$ was largely present in the non-resistant fraction. The global contamination factor of trace metals decreased with soil depth. The mobility and bioavailability were greatest for $\mathrm{Zn}$, followed by $\mathrm{Cu}$ and $\mathrm{Pb}$.
\end{abstract}

Keywords: sequential extraction, mobility, trace elements, soils, risk assessment.

\section{Introduction}

The potential toxicity of trace metals in soil or sediment is a function of their mobility and bioavailability, which depend on the phase of the metals and the chemical and physical processes that govern transformations between phases. Trace metals cause damage to the nervous system and internal organs, as well as carcinogenic effects (Davydova, 2005; Lee et al., 2007; Maas et al., 2010). One of the most critical properties of trace metals that differentiates them from other toxic pollutants, is that they are not biodegradable (Morillo et al., 2007; Prasad, 2008; Ghaderi et al., 2012; Yang et al., 2012). Metals and metalloids in soils originate from natural sources (e.g. weathering of soil and rock, erosion, and forest fires) and anthropogenic activities (e.g. industrial effluent, fertilizers, atmospheric deposition, agricultural drainage, and the phosphate industry) (Sun et al., 2007; Szynkowska et al., 2009; Maas et al., 2010; Perez-Lopez et al., 2010; Ghaderi et al., 2012; Wali et al., 2013).

Several studies have determined the total metal contents in contaminated and non-contaminated soils (Vega et al., 2004; Covelo, 2007; Kierczak et al., 2008; Maas et al., 2010; Nemati et al., 2011; Wali et al., 2013). However, the total contents of trace metals do not provide enough information to 
understand their various forms, mobility, bioavailability, or potential risks to the environment (Davutluoglu et al., 2011; Nemati et al., 2011). In contrast, a metal speciation analysis of soil can provide a good indicator of the ecosystem quality. Metals may be present in soil in several different physicochemical phases, including sinks for soluble or exchangeable trace elements in the environment and amorphous material (Fe/Mn oxides) bound to organic matter, sulphides, or mineral fractions (residual) (Rauret et al., 1999; Zemberyov'a et al., 2006; Perez-Lopez et al., 2010; Nemanti et al., 2011). Determining their fractionation is important because the mobility and bioavailability of trace metals are highly dependent on their specific chemical forms or behaviour of binding to each soil phase.

Sequential extraction procedures have recently been developed to determine the speciation of trace metals in soil matrices. These procedures provide more information on the origin, physicochemical availabilities, mobilisation, and transport of trace metals in natural environments (Kierczak et al., 2008; Rao et al., 2010; Nemanti et al., 2011; Aiju et al., 2012). The $\mathrm{pH}$, redox potential, and organic matter can stimulate the mobilisation and retention of trace metals in the natural environment (Tessier et al., 1979; Yang et al., 2009; Naji et al., 2010). The European Community Bureau of Reference (1993) introduced a new three-step sequential extraction that has since been modified by Rauret et al. (1999). This BCR sequential extraction method analyses different fractions of metals in the soil: acid-extractable (water soluble, exchangeable, and bound to carbonates), reducible (bound to $\mathrm{Fe}$ and $\mathrm{Mn}$ oxides), oxidizable (bound to sulphides and organic matter), and residual (Zemberyov'a et al., 2006; Pueyo et al., 2008; Saracoglu et al., 2009; Raži'c and Dogo, 2010).

The phosphate fertilizer industry has been an important sector of activity in Tunisia. The transformation of phosphate ores into phosphoric acids or fertilizers has been performed in the region of Sfax (central eastern coast of Tunisia) for a long time. However, this kind of activity may be a source of environmental damages (Zairi and Rouis, 1999). Our research focuses on the impact of phosphogypse stock piles on the contamination of surrounding environment (soil and water) by trace metals and hence on assessment of risks of health damage to human population through migration of contaminants. The first research established that the study area was characterised by contamination of trace metals from the phosphate fertilizer industry, especially $\mathrm{Zn}, \mathrm{Pb}$, and $\mathrm{Cu}$ (Wali et al., 2013). At this time, we want to evaluate whether these contaminants are potentially mobile in soils. We had four specific objectives: 1) to investigate the fractionation of trace metals (TM) in soils with a modified BCR extraction scheme, 2) to determine the vertical distribution of trace metals released by the phosphate fertilizer industry, 3) to establish the potential mobility of trace metals, and 4) to predict the environmental risks.

\section{Material and methods}

\subsection{Study area and sampling design}

The area around the Sfax chemical fertilizer company produces multiple forms of phosphates. Residues from productions by this enterprise are transferred into two enormous phosphogypsumcontaining warehouses $(12 \mathrm{~m}$ high $\times 40$ ha, $30 \mathrm{~m}$ high $\times 60$ ha), located at the edge of an urban area and unloaded into the sea. Solid particles are carried by the wind and by water. Assessments of the groundwater and soil at this site revealed the existence of a highly polluted zone near the pile. In previous work we have assessed the level of trace elements content in soil around stocked solid waste 'a phosphogypsum' derived from a former phosphate fertilizers factory and investigated their factors of variation (Wali et al., 2013).

In order to investigate the potential mobility of trace metals, four selected sites were studded in this work (S1, S2, S3 and S4) at regular intervals (100 m) along the transect lines to form the dump of phosphogypsum. Moreover, the site S1 is the closest site to the source of the contamination. Three soil samples were collected at each location at depths of 20, 40, and $60 \mathrm{~cm}$. To get a homogenous representative sample, each depth sample corresponds to a mixture of three sampling corners forming a triangle in the centre of the field and having edges of $2 \mathrm{~m}$ in length. A total of 12 subsamples were collected in December 2011. These sites have been shown to be highly contaminated by Wali et al. (2013), and concentrations of TM are above soil screening values defined for Europe or the USA as described by Bouguerra et al. (2012). Additional characterisations were performed in order to evaluate mobility of TM. The reference soil samples are collected from a nonurban region (El Hajeb site) located at around $17 \mathrm{~km}$ from the southwest of the study area.

\subsection{Reagent and apparatus}

All of the reagents used to digest samples were of analytical reagent grade. These reagents included ultra-pure $\mathrm{HNO}_{3}(69 \%)$ and $\mathrm{HF}(48 \%)$ by Fluka, and ultra-pure $\mathrm{HClO}_{4}(70 \%)$ and $\mathrm{HCl}(35 \%)$ by Sigma. Most reagents used for sequential extraction were of analytical grade and supplied by Merck (Germany). These reagents included $\mathrm{C}_{2} \mathrm{H}_{4} \mathrm{O}_{2}$ glacial, $\mathrm{HONH}_{2} \cdot \mathrm{HCl}$ (Merck pro-analysis), and $\mathrm{C}_{2} \mathrm{H}_{3} \mathrm{O}_{2} \mathrm{NH}_{4}$. Suprapur $\mathrm{H}_{2} \mathrm{O}_{2}(30 \%)$, also of analytical grade, was provided by Chem Lab.

\subsection{Analysis of physical and chemical properties}

Soil samples were air-dried at room temperature (RT; 20-25 ${ }^{\circ} \mathrm{C}$ ), sieved through a 200- $\mu \mathrm{m}$ mesh screen (after removing stones or other debris), and stored in polyethylene bottles until further use. Electrical conductivity (EC) and $\mathrm{pH}$ were measured in mixtures at a 1:5 (material/water) ratio, according to 
the method described by Rayment and Higginson (2002). Total organic carbon (TOC) was determined using the modified Springer-Klee method (Ciavatta et al., 1989). Cation exchange capacity (CEC) was determined according to ISO 234 (2007). The calcium carbonate $\left(\mathrm{CaCO}_{3}\right)$ composition was determined by the method described by the US Salinity Laboratory (1954).

\subsection{Analysis of element contents}

\subsubsection{Total metal digestion}

Total metal concentrations were determined by digestion with tri-acidic $\left(\mathrm{HF}-\mathrm{HClO}_{4}-\mathrm{HCl}\right)$ solutions, according to the technical protocol developed by AFNOR Certification: NF X 31-147. Digests were filtered through Whatman filter paper into $25 \mathrm{~mL}$ flasks. Certified references (MRI-E, 2005) were used to check the accuracy of the results. Recovery rates for the analysed elements were as follows: $99 \%, 98 \%$, $99 \%, 96 \%, 97 \%, 96 \%, 104 \%$, and $98 \%$ for $\mathrm{Co}, \mathrm{Ni}, \mathrm{Cr}$, $\mathrm{Pb}, \mathrm{Zn}, \mathrm{Cu}, \mathrm{Mn}$, and $\mathrm{Fe}$, respectively.

\subsubsection{BCR sequential extraction procedure}

Soil samples were analysed by the modified BCR three step sequential extraction procedure described by Nemati et al. (2011) and Davutluoglu et al. (2011). Sequential extractions were applied to $1 \mathrm{~g}$ of soil samples in $50 \mathrm{~mL}$ capacity centrifuge tubes after drying the soil samples at $105^{\circ} \mathrm{C}$ to constant weight. Sequential extractions were performed for each fraction by different forms of association and mechanisms of availability. First, we used a weak acid that releases soluble metals to extract the exchangeable fraction and the metals present in ionic form and bound to carbonates. Second, for the extraction of the reducible fraction, metals were specifically adsorbed or co-precipitated in iron and manganese and released by reduction. In the organic fraction, the metals were complexed, adsorbed and made available through oxidation. Metals in the residual fraction were only available by digestion with strong acids. Each extraction represented a different level of availability.

Sequential extraction involved three main steps and a fourth step as added by Rauret et al. (1999). In the first step, the exchangeable and soluble fractions were extracted. We mixed $1 \mathrm{~g}$ of each soil sample with $40 \mathrm{~mL}$ of $0.11 \mathrm{~mol} \mathrm{~L}^{-1}$ acetic acid solution in a mechanical end-over-end shaker at $30 \pm 10 \mathrm{rpm}$ at RT for $16 \mathrm{~h}$. The extract was separated from the solid residue by centrifugation at $3000 \mathrm{rpm}$ for $20 \mathrm{~min}$ and collected in polyethylene bottles. The residue was washed by shaking for $15 \mathrm{~min}$ with $20 \mathrm{~mL}$ of deionized water and centrifuged for $20 \mathrm{~min}$ at 3,000 rpm. The resulting supernatant was discarded.

In the second step, the reducible fraction was extracted. We added $40 \mathrm{~mL}$ of $0.5 \mathrm{~mol} / \mathrm{L}$ hydroxyl ammonium chloride solution to the residue from the first step, and re-suspended the mixture by mechanical shaking for $16 \mathrm{~h}$ at RT. The acidity level of this reagent was adjusted to $\mathrm{pH} 1.5$ with $\mathrm{HNO}_{3}$. The extract was separated, and the residue was washed in the same manner as described in the first step.

In the third step, the oxidizable fraction was extracted. We cautiously added $10 \mathrm{~mL}$ of $8.8 \mathrm{~mol} \mathrm{~L}^{-1}$ $\mathrm{H}_{2} \mathrm{O}_{2}$ solution to the residue from the second step and digested the mixture for $1 \mathrm{~h}$ at $\mathrm{RT}$ and $1 \mathrm{~h}$ at $85 \pm 2{ }^{\circ} \mathrm{C}$. The volume was reduced to less than $3 \mathrm{~mL}$. A second aliquot of $10 \mathrm{~mL}$ of $\mathrm{H}_{2} \mathrm{O}_{2}$ was added to the mixture, which was digested for $1 \mathrm{~h}$ at $85 \pm 2{ }^{\circ} \mathrm{C}$ until the volume of the residue reached 2 to $3 \mathrm{~mL}$. The residue was mixed with $50 \mathrm{~mL}$ of $1 \mathrm{~mol} \mathrm{~L}^{-1}$ ammonium acetate solution, adjusted to $\mathrm{pH} 2$ with $\mathrm{HNO}_{3}$ and shaken for $16 \mathrm{~h}$ at RT. The extract was separated, and the residue was washed in the same manner as described in previous steps.

In the fourth step, the residual fraction was extracted (Rauret et al., 1999). The residue from the third step was digested using a $\mathrm{HF}-\mathrm{HClO}_{4}-\mathrm{HCl}$ solution. Two independent replicates were performed in parallel for each sample, and blanks were measured for each set of analyses using tri-acid extraction and BCR procedures, respectively. An internal check was performed on the sequential extraction results by comparing the total amounts of metals extracted by different reagents during the sequential extraction procedure with the results obtained by total digestion.

Recovery of the sequential extraction was calculated as follows:

$$
\begin{aligned}
\operatorname{Recovery}(\%)= & \frac{\text { Step } 1+\text { Step } 2+\text { Step } 3+\text { Step } 4}{\text { Total digestion }} \\
& \times 100
\end{aligned}
$$

\subsubsection{DTPA extraction method}

The available metal contents in soils were determined by using $0.005 \mathrm{~mol} \mathrm{~L}^{-1}$ diethylene triamine pentaacetic acid (DTPA), $0.01 \mathrm{~mol} \mathrm{~L}^{-1} \mathrm{CaCl}_{2}$, and $0.1 \mathrm{~mol} \mathrm{~L}^{-1}$ triethanolamine (TEA). Twenty millilitres of DTPA ( $\mathrm{pH}=7.3$ ) solution were added to soil samples $(10 \mathrm{~g})$ that had been placed in polypropylene bottles. The bottles were shaken on mechanical shakers for $2 \mathrm{~h}$ and then centrifuged for $10 \mathrm{~min}$ at $3000 \mathrm{rpm}$. The supernatant was discarded (Luo et al., 2012).

\subsection{Determination of individual and global contamination factor}

Individual contamination factors (ICFs) and the global contamination factor (GCF) evaluates the degree of toxicity or risk to the environment and the bioavailability of trace metals in the soil relative to its retention time. In this study, ICFs were calculated for the three layers at all sites as the sum of the concentrations of trace metals extracted in the first three steps (exchangeable, acid-reducible, and oxidizable-organic forms) divided by the concentration in the residual fraction (Jamali et al., 2007; Nemati et al., 2011).The GCF was calculated 
by summing the ICFs of heavy metals (Naji et al., 2011; Aiju et al., 2012).

\section{$3 \quad$ Results and discussion}

\subsection{Soil characteristics}

The obtained results for selected physicchemical properties of soil samples were summarised in Table 1. In fact, $\mathrm{pH}$ in soils was in slightly alkaline condition and ranged from 7.55 to 8.75 . The exception to this finding was at site $\mathrm{S} 1$, where the soil $\mathrm{pH}$ was acidic in the top layer ( $\mathrm{pH}$ 6.30) but increased with depth (Table 1). An alkaline soil is associated with the presence of $\mathrm{CaCO}_{3}$ (Wali et al., 2013). Soil alkalinity increases the adsorption capacity of oxides, including manganese and iron hydroxides, which are strong natural adsorbents (Bozkurt et al., 2000).

The cation exchange capacity of soil depends on the amount and type of soil colloids present, the soil $\mathrm{pH}$, and the organic matter content of the soil. The CEC ranged from 7.24 to $16.5 \mathrm{cmol} \mathrm{kg}^{-1}$. The minimum value was found in the top layer of site $\mathrm{S} 1$, which also had the maximum amount of total organic carbon. Values for TOC ranged from $0.16 \%$ to $2.05 \%$. The distribution of $\mathrm{pH}, \mathrm{EC}, \mathrm{CEC}$, and TOC among the sites showed a significant impact of anthropogenic pollution by phosphogypsum, especially at site S1.

Table 1. Physical and chemical properties of the four soil samples (sites S1-S4) at three depths.

\begin{tabular}{||c|c|c|c|c|c|c|c|c|c|c|c|c||}
\hline Site & \multicolumn{3}{|c|}{ S1 } & \multicolumn{3}{c|}{ S2 } & \multicolumn{3}{c|}{ S3 } & \multicolumn{3}{c|}{ S4 } \\
\hline Parameters & $20 \mathrm{~cm}$ & $40 \mathrm{~cm}$ & $60 \mathrm{~cm}$ & $20 \mathrm{~cm}$ & $40 \mathrm{~cm}$ & $60 \mathrm{~cm}$ & $20 \mathrm{~cm}$ & $40 \mathrm{~cm}$ & $60 \mathrm{~cm}$ & $20 \mathrm{~cm}$ & $40 \mathrm{~cm}$ & $60 \mathrm{~cm}$ \\
\hline $\mathbf{p H}$ & 6.30 & 7.55 & 8.23 & 8.72 & 8.62 & 8.57 & 8.47 & 8.75 & 8.74 & 8.11 & 8.02 & 8.11 \\
\hline $\begin{array}{c}\mathbf{E C} \\
\left(\mathbf{m S ~ c m}^{-1}\right)\end{array}$ & 13.60 & 9.00 & 8.30 & 7.50 & 8.10 & 7.40 & 4.20 & 5.60 & 5.40 & 0.63 & 2.40 & 2.50 \\
\hline $\begin{array}{c}\mathbf{C E C} \\
\left(\mathbf{c m o l ~ k g}^{-1}\right)\end{array}$ & 16.50 & 15.59 & 12.92 & 10.89 & 11.09 & 11.85 & 11.94 & 11.09 & 11.94 & 8.63 & 7.77 & 7.24 \\
\hline TOC (\%) & 2.05 & 0.63 & 0.41 & 1.76 & 0.87 & 0.69 & 0.52 & 0.87 & 0.16 & 0.77 & 0.36 & 0.36 \\
\hline $\mathbf{C a C O}_{\mathbf{3}}(\boldsymbol{\%})$ & 10.25 & 13.38 & 16.88 & 21.12 & 18.63 & 19.00 & 16.25 & 17.25 & 15.00 & 13.13 & 12.38 & 14.9 \\
\hline
\end{tabular}

\subsection{Distribution of the total concentration of trace metals with distance and depth}

Most of the trace metals were more concentrated in the topsoil $(0-20 \mathrm{~cm})$ than in the subsoil samples
(20-40 cm and $40-60 \mathrm{~cm}$ ) at the four sites, with similar trends with depth, except for $\mathrm{Pb}, \mathrm{Ni}, \mathrm{Co}, \mathrm{Mn}$, and $\mathrm{Fe}$ at site $\mathrm{S} 2 ; \mathrm{Mn}$ and $\mathrm{Fe}$ at site $\mathrm{S} 3$; and $\mathrm{Cu}, \mathrm{Co}$, $\mathrm{Cr}, \mathrm{Ni}, \mathrm{Fe}$, and $\mathrm{Mn}$ at site S4 (Table 2).

Table 2. Total concentrations of trace metals $(\mathrm{mg} / \mathrm{kg})$, sum of the trace metals extracted at each step of the sequential extraction procedure, and extraction efficiencies $(\Sigma(F 1-F 4) / T o t a l$, where $F 1-F 4$ are the four steps of the procedure) for the four soil samples (sites S1-S4).

\begin{tabular}{|c|c|c|c|c|c|c|c|c|c|c|c|c|c|}
\hline & \multicolumn{3}{|c|}{ S1 } & \multicolumn{3}{|c|}{ S2 } & \multicolumn{3}{|c|}{ S3 } & \multicolumn{3}{|c|}{ S4 } \\
\hline & & $\begin{array}{l}20 \\
\text { cm }\end{array}$ & $\begin{array}{l}40 \\
\mathrm{~cm}\end{array}$ & $\begin{array}{l}60 \\
\mathrm{~cm}\end{array}$ & $\begin{array}{l}20 \\
\text { cm }\end{array}$ & $\begin{array}{l}40 \\
\text { cm }\end{array}$ & $\begin{array}{l}60 \\
\mathrm{~cm}\end{array}$ & $\begin{array}{l}20 \\
\mathrm{~cm}\end{array}$ & $\begin{array}{l}40 \\
\mathrm{~cm}\end{array}$ & $\begin{array}{l}60 \\
\mathrm{~cm}\end{array}$ & $\begin{array}{l}20 \\
\mathrm{~cm}\end{array}$ & $\begin{array}{l}40 \\
\mathrm{~cm}\end{array}$ & $\begin{array}{l}60 \\
\mathrm{~cm}\end{array}$ \\
\hline \multirow[t]{3}{*}{$\mathrm{Zn}$} & $\mathrm{TC}$ & 282.10 & 94.45 & 48.53 & 95.15 & 76.54 & 54.63 & 59.45 & 39.10 & 24.56 & 38.25 & 23.28 & 31.56 \\
\hline & SoE & 308.05 & 85.73 & 49.95 & 91.57 & 77.43 & 50.78 & 55.53 & 36.67 & 25.43 & 37.64 & 24.08 & 28.14 \\
\hline & $\begin{array}{c}\Sigma(\mathrm{F} 1-\mathrm{F} 4) \\
/ 100 \%\end{array}$ & 109.20 & 90.76 & 102.92 & 96.23 & 101.16 & 92.95 & 93.40 & 93.78 & 103.5 & 98.40 & 103.43 & 89.16 \\
\hline \multirow[t]{3}{*}{$\mathrm{Pb}$} & TC & 30.51 & 19.61 & 24.41 & 31.09 & 33.58 & 31.31 & 30.66 & 23.83 & 22.51 & 33.96 & 21.72 & 25.65 \\
\hline & SoE & 72.38 & 42.66 & 39.22 & 47.96 & 42.90 & 34.92 & 40.84 & 35.42 & 30.32 & 30.03 & 25.51 & 26.41 \\
\hline & $\begin{array}{c}\Sigma(\mathrm{F} 1-\mathrm{F} 4) \\
/ 100 \%\end{array}$ & 237.23 & 217.23 & 160.67 & 154.26 & 127.75 & 111.52 & 133.2 & 148.6 & 134.69 & 88.42 & 117.45 & 102.9 \\
\hline \multirow[t]{3}{*}{$\mathrm{Cu}$} & TC & 49.42 & 14.50 & 10.51 & 23.63 & 14.89 & 12.88 & 16.90 & 13.21 & 7.25 & 8.59 & 10.35 & 12.12 \\
\hline & SoE & 47.97 & 14.78 & 11.90 & 21.89 & 15.10 & 12.46 & 16.53 & 10.87 & 7.20 & 8.71 & 7.78 & 10.05 \\
\hline & $\begin{array}{c}\Sigma(\mathrm{F} 1-\mathrm{F} 4) \\
/ 100 \%\end{array}$ & 97.06 & 101.93 & 113.22 & 92.63 & 101.41 & 96.74 & 97.81 & 82.28 & 99.31 & 101.39 & 75.17 & 82.92 \\
\hline \multirow[t]{3}{*}{$\mathrm{Ni}$} & TC & 23.13 & 17.52 & 10.47 & 11.13 & 12.46 & 11.90 & 12.00 & 11.11 & 8.03 & 6.82 & 7.67 & 7.09 \\
\hline & SoE & 20.13 & 16.68 & 7.81 & 6.20 & 7.23 & 7.55 & 8.25 & 7.25 & 5.23 & 4.62 & 4.16 & 3.78 \\
\hline & $\begin{array}{c}\Sigma(\mathrm{F} 1-\mathrm{F} 4) \\
/ 100 \%\end{array}$ & 87.03 & 95.20 & 74.59 & 55.7 & 58.02 & 63.44 & 68.75 & 65.25 & 65.13 & 67.74 & 54.23 & 53.31 \\
\hline \multirow[t]{3}{*}{$\mathrm{Cr}$} & TC & 82.35 & 25.66 & 27.38 & 27.24 & 25.57 & 26.62 & 24.44 & 24.07 & 21.60 & 17.69 & 17.65 & 18.39 \\
\hline & SoE & 194.70 & 50.98 & 48.97 & 40.24 & 40.64 & 43.46 & 35.47 & 28.80 & 19.10 & 23.77 & 17.39 & 15.75 \\
\hline & $\begin{array}{c}(\mathrm{F} 1-\mathrm{F} 4) \\
/ 100 \%\end{array}$ & 236.43 & 198.67 & 178.85 & 147.72 & 158.89 & 163.26 & 145.13 & 119.65 & 88.42 & 134.36 & 98.52 & 85.64 \\
\hline \multirow[t]{3}{*}{ Co } & TC & 5.27 & 6.05 & 5.43 & 3.61 & 5.26 & 4.49 & 5.28 & 3.01 & 2.85 & 3.04 & 3.47 & 2.85 \\
\hline & SoE & 7.51 & 5.41 & 5.72 & 4.99 & 5.34 & 4.88 & 5.47 & 3.36 & 2.45 & 2.79 & 3.03 & 3.18 \\
\hline & $\begin{array}{c}\Sigma(\mathrm{F} 1-\mathrm{F} 4) \\
/ 100 \%\end{array}$ & 142.50 & 89.42 & 105.34 & 138.22 & 101.52 & 108.68 & 103.59 & 111.62 & 85.96 & 91.77 & 87.31 & 111.60 \\
\hline
\end{tabular}




\begin{tabular}{|c|c|c|c|c|c|c|c|c|c|c|c|c|c|}
\hline & \multicolumn{3}{|c|}{ S1 } & \multicolumn{3}{|c|}{$\overline{\mathrm{S} 2}$} & \multicolumn{3}{|c|}{$\overline{\mathrm{S3}}$} & \multicolumn{3}{|c|}{$\overline{S 4}$} \\
\hline & & $\begin{array}{l}20 \\
\mathrm{~cm}\end{array}$ & $\begin{array}{l}40 \\
\mathrm{~cm}\end{array}$ & $\begin{array}{l}60 \\
\mathrm{~cm}\end{array}$ & $\begin{array}{l}20 \\
\mathrm{~cm}\end{array}$ & $\begin{array}{l}40 \\
\mathrm{~cm}\end{array}$ & $\begin{array}{l}60 \\
\mathrm{~cm}\end{array}$ & $\begin{array}{l}20 \\
\mathrm{~cm}\end{array}$ & $\begin{array}{l}40 \\
\mathrm{~cm}\end{array}$ & $\begin{array}{l}60 \\
\mathrm{~cm}\end{array}$ & $\begin{array}{l}20 \\
\text { cm }\end{array}$ & $\begin{array}{l}40 \\
\mathrm{~cm}\end{array}$ & $\begin{array}{l}60 \\
\mathrm{~cm}\end{array}$ \\
\hline \multirow[t]{3}{*}{$\mathrm{Mn}$} & TC & 238.70 & 246.65 & 227.03 & 159.99 & 212.59 & 221.75 & 190.98 & 198.12 & 174.04 & 126.38 & 225.58 & 187.00 \\
\hline & SoE & 271.34 & 241.65 & 215.89 & 167.96 & 214.23 & 212.10 & 202.95 & 186.26 & 149.81 & 124.95 & 213.56 & 177.10 \\
\hline & $\begin{array}{c}\text { (F1-F4) } \\
/ 100 \%\end{array}$ & 113.67 & 97.97 & 95.09 & 104.98 & 100.77 & 95.64 & 106.26 & 94.01 & 86.07 & 98.86 & 94.67 & 94.70 \\
\hline \multirow[t]{3}{*}{$\mathrm{Fe}$} & TC & 35.847 & 19.624 & 16.586 & 11.171 & 14.763 & 15.586 & 13.698 & 14.339 & 9.768 & 8.514 & 9.161 & 8.124 \\
\hline & SoE & 24.778 & 16.434 & 14.800 & 10.830 & 13.462 & 14.160 & 13.741 & 12.184 & 9.477 & 8.262 & 8.858 & 7.753 \\
\hline & $\begin{array}{c}\Sigma(\mathrm{F} 1-\mathrm{F} 4) \\
/ 100 \%\end{array}$ & 69.12 & 83.37 & 89.23 & 96.94 & 91.18 & 90.85 & 100.31 & 84.97 & 97.02 & 97.04 & 96.69 & 95.43 \\
\hline
\end{tabular}

$T C=$ Total concentration, $\mathrm{SoE}=$ Sum of extracted

The total concentrations of trace metals were higher at site S1 (i.e. near the source of contamination) than site S4 (Table 2). The amounts of trace metals decreased gradually with increasing distance from the dump of phosphogypsum and with increasing soil depth. Our results suggest that anthropogenic contamination of the sites by trace metals in the topsoil came from traffic emissions, local industrial emissions, particularly by the phosphate fertilizer industry. We consider site S4 to be the local natural background that was not affected by anthropogenic contamination. Regarding these results, it is obvious that the concentrations of trace metals in the PG surrounding area are much higher than the reference soil. However, the concentrations of $\mathrm{Zn}, \mathrm{Cu}, \mathrm{Cr}, \mathrm{Pb}, \mathrm{Ni}$ and $\mathrm{Co}$ in reference soil were $11.2,7.7,7.1,4.4,3.4$, and 1.1 , respectively. Thus, the amount of pollution that can often enter the surrounding environment can have a negative impact on the quality of human life and the environment.

The total amount of trace metals in the soil is controlled by significant factors including $\mathrm{pH}$, Eh, composition and amount of organic matter in the soil, clay mineral content, salt concentrations, anion and cation complexion agents, and presence of $\mathrm{Fe} / \mathrm{Mn} / \mathrm{Al}$ oxides and hydroxides (Hursthouse, 2001; Horckmans et al., 2007). The top layer of soil at site S1 had a lower $\mathrm{pH}$ and higher TOC compared to the other layers and sites (Table 1). These observations confirm the high concentrations of trace metals at this location.

\subsection{Sequential extraction of metals}

The accuracy values of $\mathrm{Zn}, \mathrm{Cu}, \mathrm{Mn}$, and $\mathrm{Fe}$ ranged between 69.12 and $113.67 \%$ in all sites were similar to those obtained by other researchers (Cuong et al., 2006; Umoren et al., 2007; Favas et al., 2011). However, values were higher in the polluted saline soils at sites S1 and S2 for Cr (147.72-236.43\%) and $\mathrm{Pb}(111.52-237.23 \%)$. It is hypothesized that $\mathrm{Cr}$ and $\mathrm{Pb}$ in these samples are associated with HF-refractory minerals such as iron and manganese oxides, which act as a trap for trace elements. These oxides are excellent scavengers for trace metals and can be mobilised under acidic conditions (Issaron et al., 2009). The high recovery can be explained by the lower efficiency of digestion of the HF acid mixture with high $\mathrm{Ca}$ content, which trapped calcium fluoroaluminate or calcium precipitates and was affected by interferences. Calcareous soil digestion without HF has produced better results than procedures using $\mathrm{HF}$, with recoveries from $80 \%$ to $114 \%$ (Vandecasteele et al., 2003) and $45 \%$ to $173 \%$ (Bettinelli et al., 2000). Moreover, digesting calcareous soil with HF has been shown to prevent complex, formation, to create a white precipitate, and to lead to interferences (Rao et al., 2010; GarcíaDelgado et al., 2012).

Free calcium carbonate renders the soil $\mathrm{pH}$ as alkaline, which decreases the bioavailability of trace metals by increasing the adsorptive capacity of the soil (Gasparatos et al., 2001). A reduction in soil $\mathrm{pH}$ increases the bioavailability and mobility of metals (Papafilippaki et al., 2008). Therefore, quantifying the metal speciation in the soil solution provides valuable information on the degree of contamination, as well as potential environmental and human health risks. We used an optimised BCR sequential extraction procedure to determine the operationally defined fraction. The exchangeable fraction of $\mathrm{Zn}$ in the surface layer ranged from $9.92 \%$ at site S3 to $22.69 \%$ at site $\mathrm{S} 4$, and the reducible fraction ranged from $32.78 \%$ at site S3 to $57.26 \%$ at site S1 (Fig. 1). Higher levels of the acid-reducible fraction of $\mathrm{Zn}$ can be attributed to the affinity of this metal to metals associated with manganese and iron oxides or hydroxides. However, iron and manganese oxides bond to trace metals and are found in the acidreducible fraction, which has a high scavenging efficiency for trace metals (Naji et al., 2010; Aiju et al., 2012). This association makes an important contribution to the total concentration of $\mathrm{Zn}$ extracted from the soil, suggesting that some $\mathrm{Zn}$ may come from industrial activities that extensively use phosphate fertilizer. The oxidizable fraction of $\mathrm{Zn}$ had a maximum of $5.55 \%$ at site $\mathrm{S} 1$, and the residual fraction ranged from $17.29 \%$ at site $\mathrm{S} 1$ to $55.38 \%$ at site S3. Comparisons among resistant and nonresistant fractions of $\mathrm{Zn}$ in the topsoil at each site showed that the mobility and bioavailability of metals decreased from sites S1 to S4. The non-resistant fraction (sum of the exchangeable, reducible, and oxidizable fractions) is potentially toxic for organisms. The exchangeable fraction is easily removed and used by organisms, whereas the reducible and oxidizable fractions can be solubilised depending on the physical and chemical parameters, 
such as the oxygen content, Eh, charges, salinity, and bacterial activity (Yap et al., 2006).

The proportion of $\mathrm{Zn}$ in the surface soil was in the following order: reducible $>$ residual $>$ exchangeable > oxidizable (except at site $\mathrm{S} 1$, where exchangeable $>$ reducible $>$ residual $>$ oxidizable). Similar results were reported in surface sediments from Malaysia (Naji et al., 2010; Neamti et al., 2011). These studies suggest that $\mathrm{Zn}$ is the most labile metal because of its stronger affinity for the non-residual fraction. Zn was mainly associated with the residual
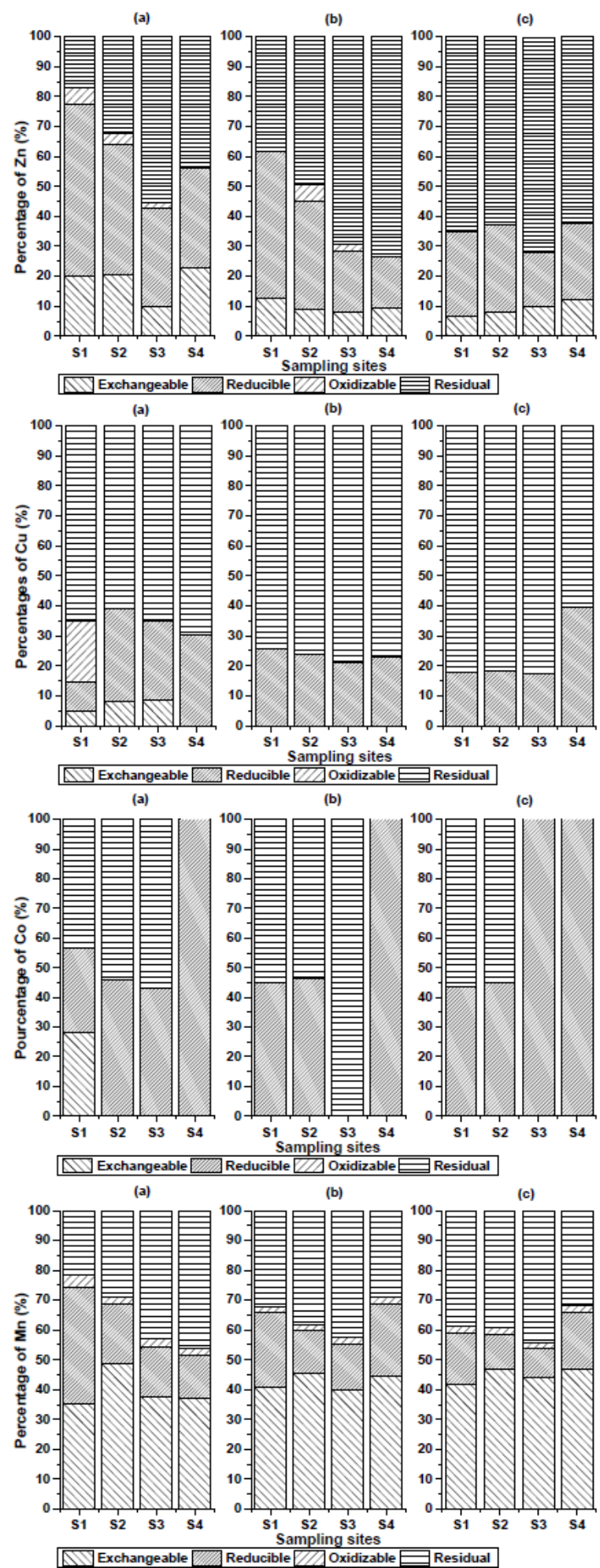

Figure 1. Metal fractionation of contaminated soils at the four sites (S1-S4) obtained by sequential extractions (BCR method): (a) 0-20 cm; (b) 20-40 cm; (c): 40-60 cm. fraction in the two deeper layers $(>60 \%$ of the total fraction, Fig. 1), except for the middle layer at sites S1 and S2, with the following order of mobility (greatest to least mobile): residual > reducible > exchangeable $>$ oxidizable. Metals of natural origin have low lability and bioavailability in soil. Kierczak et al. (2008) made a similar observation for urban and industrialised areas but found that $\mathrm{Zn}$ was associated with the residual fraction.
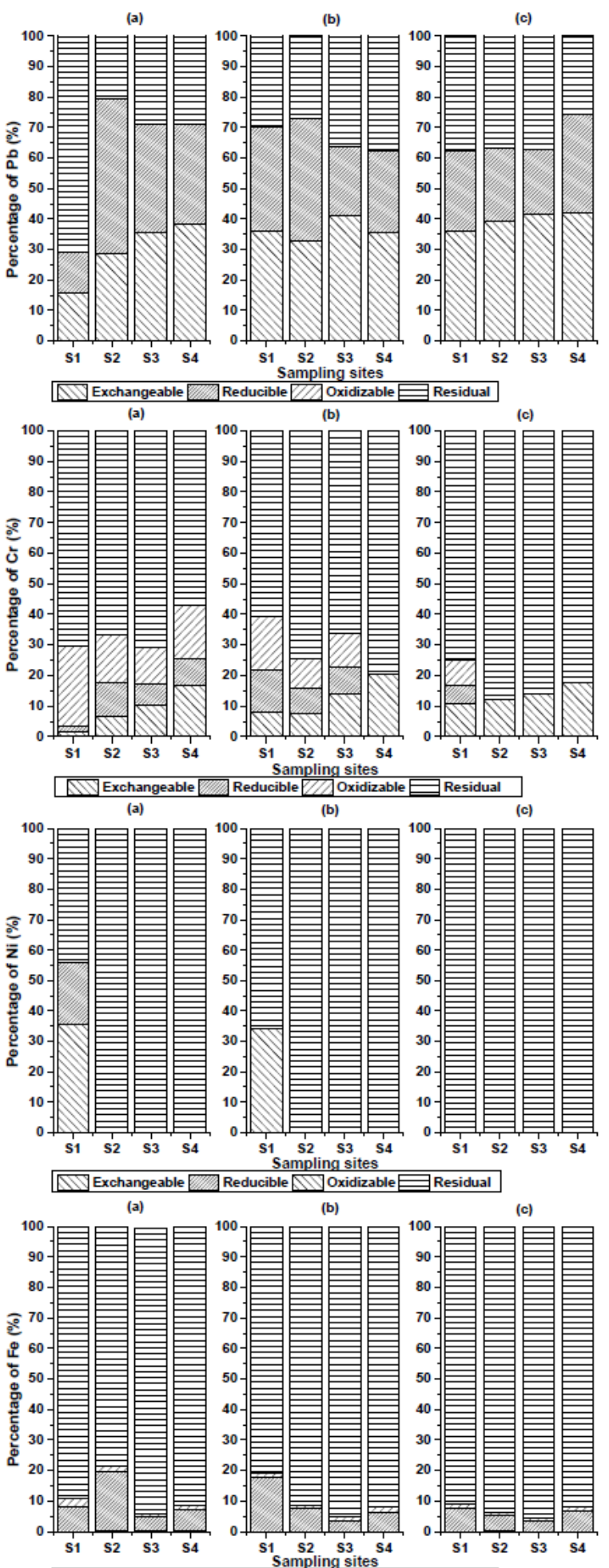

Exchangeable Reduciblemplagidizable are mainly bound to aluminosilicates and, therefore, 
Several sequential extraction procedures, including the BCR method, have been used to obtain information about the distribution of $\mathrm{Pb}$ in sediments (Yuan, 2004; Nemati et al., 2011; Yang et al., 2012) and other samples, such as soil (Kierczak et al., 2008; Favas et al., 2011). Approximately $60 \%$ of the $\mathrm{Pb}$ was bound to the non-residual (exchangeable and reducible) fraction at all sites and all soil depths (except for site $\mathrm{S} 1$, where most of the $\mathrm{Pb}$ was found in the residual fraction; Fig. 1).The presence of $\mathrm{Pb}$ in the reducible fraction suggests that $\mathrm{Fe}-\mathrm{Mn}$ oxides are involved in trapping this element for $\mathrm{pH}$ values above 7 (Nafeh Kassir etal., 2012). A high percentage of carbonate (>10\%) indicates the association of $\mathrm{Pb}$ with carbonate, which is similar to what Kierczak et al. (2008) found in contaminated soil with waste dump.

The highest percentage of $\mathrm{Pb}$ was found in the exchangeable, rather than the residual, fraction at most sites (S2-S4), indicating that $\mathrm{Pb}$ is more mobile and potentially more bioavailable at these sites than at site S1. D'iaz-de Alba et al. (2011) found similar results for $\mathrm{Pb}$ in regions influenced by anthropogenic activities, with trace metals that were mostly found in the labile fraction. Compared to metals of natural origin, anthropogenic metals are more loosely associated with the soil. These metals may be released back to the aqueous phase with a change in the physical and chemical soil characteristics (Eh, pH, salinity, and the content of organic chelators). The percentage of $\mathrm{Pb}$ in the non-residual fraction decreased with the increase of depth.

$\mathrm{Cu}$ was only associated with two or three soil fractions in the top layer, except at S1 where it was distributed among all fractions in the following order (greatest to least percentage): residual > oxidizable > reducible > exchangeable fractions (Fig. 1).The high percentage of $\mathrm{Cu}$ in the oxidizable fraction $(20.35 \%)$ extracted from the topsoil at site S1 may be explained by the high affinity of the soluble organic fraction. $\mathrm{Cu}$ also was bound to various forms of organic matter by complexation or bioaccumulation. More than $30 \%$ of $\mathrm{Cu}$ was bound to the non-residual fraction at all sites (> 40\% at site S1), which represents an environmental risk. The non-residual fraction showed a normal reducing trend with increasing distance from the source of contamination. Most of the $\mathrm{Cu}$ in the two deeper layers was found in the residual fraction at all sites. $\mathrm{Cu}$ appeared mainly in iron and manganese oxides $(39.70 \%)$ and in the residual fraction $(60.30 \%$; except in the deepest layer at site S4); similar results were reported by Castillo-Carrion et al. (2007) in contaminated soil. The association of $\mathrm{Cu}$ with the residual fraction in the subsoil more than the topsoil suggests that $\mathrm{Cu}$ was linked to the resistant mineralogical phases in the surface soil and, therefore, was more labile and bioavailable in the soil solution.

$\mathrm{Cr}$ was found in all fractions, except in the middle layer at site $\mathrm{S} 4$ and the deepest layer at sites S2-S4 (Fig. 1). The dominant phase was in the residual fraction, which accounted for more than $50 \%$ in our study and was also found by Kierczak et al. (2008) and Davutluoglu et al. (2011). Metals associated with the residual fraction are likely to be incorporated in alumino-silicate minerals. A greater percentage of $\mathrm{Cr}$ was found in the non-residual fraction (exchangeable, reducible, and oxidizable fractions) in the topsoil compared to the subsoil. However, the topsoil at all sites contained up to $10 \%$ of $\mathrm{Cr}$ within the sulfidic/organic fraction. The percentage of $\mathrm{Cr}$ in the oxidizable fraction decreased slightly with depth. This finding can be explained by the reduction in organic matter (Table 1) and the high correlation of $\mathrm{Cr}$ with TOC (Wali et al., 2013). However, the percentage of $\mathrm{Cr}$ in the exchangeable fraction increased gradually from S1 to S4 and with depth. At top layer the exchangeable fraction in the surface layer ranged from $1.61 \%$ at site $\mathrm{S} 1$ to $16.66 \%$ at site S4. At middle layer, the exchangeable fraction ranged from $7.31 \%$ at site $\mathrm{S} 2$ to $20.30 \%$ at site $\mathrm{S} 4$ and at a depth layer ranged from $10.56 \%$ at site $\mathrm{S} 1$ to $17.71 \%$ at site S4. Generally, the mobility of $\mathrm{Cr}$ in all soil samples was in the following order: at a depth of $20 \mathrm{~cm}$, residual > oxidizable > exchangeable > reducible, and at depths of 40 and $60 \mathrm{~cm}$, residual > exchangeable $>$ oxidizable $>$ reducible, except at site 4 in the middle layer $(20-40 \mathrm{~cm})$ and at sites $\mathrm{S} 2$, S3 and S4 at the deepest $(40-60 \mathrm{~cm})$ (Fig. 1).

At site S1 in the top layer Co was generally distributed among the carbonate $(28.07 \%)$, reducible $(28.61 \%)$ and residual fractions $(43.32 \%)$, but only among the reducible the fraction ranged from $45.19 \%$ to $43.53 \%$, and residual fractions ranged from $54.81 \%$ to $56.47 \%$ from the middle to deeper layers, respectively (Fig. 1). However, Co was only bound to the reducible fraction at all depths at site S4 and in the deepest layer at site S3. This result at site S3 can be explained by the association of Co with iron and manganese oxides and hydroxides from industrial pollution in this area. In the absence of sulphides, the reductive dissolution of iron and manganese oxides could fix Fe and $\mathrm{Mn}$ as the sulphide phase, followed by precipitation upon crossing the oxic/anoxic boundary (Nemati el al., 2011).

Most of the Ni and Fe were held in the residual fraction in all layers at most sites, except in the top two layers at site S1 for Ni (Fig. 1). Similar results have been reported by Kierczak et al. (2008) at contaminated soil and sediment in the Pearl River Estuary in China (Yu et al., 2010; Yang et al., 2012). A significant association of $\mathrm{Fe}$ and $\mathrm{Ni}$ with the residual fraction can be explained by the link to more resistant mineralogical phases, such as crystalline iron oxide and residual silicate phases. However, the difference in the distribution of $\mathrm{Ni}$ among the different fractions in the top two layers at site S1 may be explained by the strong affinity of $\mathrm{Ni}$ and $\mathrm{Fe}$ in these fractions, suggesting that these metals were primarily contained in silicates and other resistant materials. The dominant proportion of $\mathrm{Fe}$ and $\mathrm{Ni}$ was in the residual fraction. Similar results have also been reported by Martin et al. (1999); Davutluoglu et al. (2011) and Favas et al. (2011). Minerals in the residual fraction are strongly bonded to metals and do not represent an environmental risk. 
Unlike $\mathrm{Ni}$, Co and $\mathrm{Pb}, \mathrm{Mn}$ was found in all fractions at all sites and depths (Fig. 1) as reported by Yuan et al. (2004) and Davutluoglu et al. (2011). In fact, Mn was extensively released into the carbonate and acid-soluble fractions (D'raz-de Alba et al., 2011). Generally, the percentage of $\mathrm{Mn}$ in all soil samples was in the following order: exchangeable > residual $>$ reducible $>$ oxidizable. The percentage in the exchangeable fraction in the top layer exceeded $35 \%$ at site $\mathrm{S} 1$ and reached $48.57 \%$ at site S2. Mn was the most mobile element among the elements studied, as indicated by its high amounts in the acid or watersoluble fraction. A considerable amount of manganese oxide was detected in the reducible fraction, which may be released if the soil is subjected to more reducing conditions. The percentage of $\mathrm{Mn}$ was highest in the topsoil at site S1 compared to other depths and sites, indicating a normal reduction from the source of contamination. The percentage of $\mathrm{Mn}$ in the residue fraction in all layers at all sites was usually lower than $50 \%$, similar to the behaviour of soils polluted by mining, industry, and traffic (Maiz et al., 2000).

\subsection{Environmental implications: Individual and global contamination factors}

The results of ICFs and GCF in soil samples are summarised in Table 3 . In the $0-20 \mathrm{~cm}$ layer, the highest and lowest ICF values for $\mathrm{Zn}$ were found at sites S1 and S3, respectively (Table 3), and those for $\mathrm{Pb}$ were found at sites $\mathrm{S} 2$ and $\mathrm{S} 1$, respectively. The average ICF values of $\mathrm{Cu}, \mathrm{Cr}, \mathrm{Co}, \mathrm{Mn}$, and $\mathrm{Fe}$ followed the same order for the different layers of soil, as follows: $\mathrm{Pb}>\mathrm{Zn}>\mathrm{Mn}>\mathrm{Co}>\mathrm{Cu}>\mathrm{Cr}>\mathrm{Ni}>$ $\mathrm{Fe}$. Thus, the risks of contamination by $\mathrm{Pb}$ and $\mathrm{Zn}$ at sites S1 and S2 were greater than the risks of contamination by the rest of the elements studied. The GCF showed high contamination by metals in all layers at all sites. The highest value of the GCF was found for the top layer at site $S 1$, while the lowest level was at site S4. The GCF in the top layer decreased from S1 to S4 (Table 3).

Table 3. Individual (ICF) and global contamination factors (GCF) of trace metals in the four soil samples (sites S1-S4) at three depths.

\begin{tabular}{|c|c|c|c|c|c|c|c|c|c|c|}
\hline & \multirow[t]{2}{*}{ Site } & \multicolumn{8}{|c|}{ ICF } & \multirow[t]{2}{*}{ GCF } \\
\hline & & $\mathbf{Z n}$ & $\mathbf{P b}$ & $\mathbf{C u}$ & $\mathrm{Cr}$ & Co & $\mathbf{N i}$ & Mn & $\mathrm{Fe}$ & \\
\hline \multirow{5}{*}{$\begin{array}{c}\mathbf{0 - 2 0} \\
\mathrm{cm}\end{array}$} & S1 & 4.78 & 0.41 & 0.53 & 0.42 & 1.31 & 1.26 & 3.64 & 0.12 & 12.48 \\
\hline & S2 & 2.10 & 3.91 & 0.65 & 0.50 & 0.85 & 0.00 & 2.45 & 0.27 & 9.88 \\
\hline & S3 & 0.81 & 2.48 & 0.54 & 0.41 & 0.76 & 0.00 & 1.32 & 0.06 & 6.39 \\
\hline & S4 & 1.27 & 2.46 & 0.43 & 0.75 & 1.86 & 0.00 & 1.17 & 0.1 & 6.18 \\
\hline & Mean & 2.24 & 2.31 & 0.54 & 0.52 & 1.20 & 0.32 & 2.14 & 0.14 & 8.73 \\
\hline \multirow{5}{*}{$\begin{array}{c}20-40 \\
\mathrm{~cm}\end{array}$} & S1 & 1.60 & 2.35 & 0.34 & 0.64 & 0.82 & 0.52 & 2.08 & 0.24 & 8.60 \\
\hline & S2 & 1.01 & 2.70 & 0.31 & 0.34 & 0.86 & 0.00 & 1.62 & 0.09 & 6.95 \\
\hline & S3 & 0.44 & 1.77 & 0.27 & 0.51 & 0.00 & 0.00 & 1.36 & 0.05 & 4.40 \\
\hline & S4 & 0.36 & 1.66 & 0.30 & 0.25 & - & 0.00 & 2.43 & 0.09 & 5.09 \\
\hline & Mean & 1.71 & 2.12 & 0.31 & 0.44 & 0.42 & 0.13 & 1.87 & 0.12 & 6.26 \\
\hline \multirow{4}{*}{$\begin{array}{c}40-60 \\
\mathrm{~cm}\end{array}$} & S1 & 0.56 & 1.67 & 0.21 & 0.33 & 0.77 & 0.00 & 1.56 & 0.09 & 5.18 \\
\hline & S2 & 0.59 & 1.71 & 0.22 & 0.14 & 0.81 & 0.00 & 1.54 & 0.06 & 5.07 \\
\hline & S3 & 0.39 & 1.64 & 0.21 & 0.16 & - & 0.00 & 1.25 & 0.04 & 3.69 \\
\hline & S4 & 0.61 & 2.90 & 0.66 & 0.21 & - & 0.00 & 2.13 & 0.09 & 6.63 \\
\hline \multicolumn{2}{|c|}{ Mean } & 0.54 & 1.98 & 0.33 & 0.21 & 0.39 & 0.00 & 1.62 & 0.07 & 5.14 \\
\hline
\end{tabular}

The ICF of $\mathrm{Zn}$ had a similar distribution in the $20-40 \mathrm{~cm}$ layer as in the top layer, but with lower values (Table 3 ). The highest and lowest ICF values of $\mathrm{Pb}$ in this layer were found at sites $\mathrm{S} 2$ and $\mathrm{S} 4$, respectively. The ICF of $\mathrm{Cu}$ was similar for the four sites, with a mean value of about 0.31 . There was no general trend with distance from the source of contamination for the ICFs of $\mathrm{Cr}$ and $\mathrm{Mn}$. The GCF values decreased with depth and were highest and lowest in both of the deeper layers at sites S1 and S3, respectively (Table 3 ). The high GCF in the surface soils can be explained by the tendency of trace metals to accumulate near the surface of the soil. Our results identified sites located near the phosphate fertilizer industry as having high potential environmental risks related to the toxic trace metals. Our results agree with other findings in sediments (Naji et al., 2010; Aiju et al., 2012), which show that soils are polluted with industrial, agriculture and domestic wastes that are highly contaminated by trace metals.

\subsection{Mobility and bioavailability of $\mathrm{Zn}, \mathrm{Pb}$, and $\mathrm{Cu}$}

The use of the complexing ligands DTPA and TEA and the ion $\mathrm{Ca}^{2+}$ in determining the contents of trace metals allows a fast exchange with mobile bivalent cations (especially $\mathrm{Zn}^{2+}$ and $\mathrm{Pb}^{2+}$ ) and with $\mathrm{Cu}^{2+}$, even when it is complexed with organic matter because organic $\mathrm{Cu}$ compounds have a high stability constant. Concentrations of the available selected trace metals $(\mathrm{Zn}, \mathrm{Pb}$, and $\mathrm{Cu})$ at sites $\mathrm{S} 1-\mathrm{S} 3$ were high in the upper layers and decreased gradually with depth (Fig. 2). Similar trends were seen at site S4, except that the concentration of $\mathrm{Zn}$ at $20-40 \mathrm{~cm}$ was lower than at $40-60 \mathrm{~cm}$, and the concentration of $\mathrm{Cu}$ at $40-60 \mathrm{~cm}$ was higher than at the two shallower depths. The mobility and bioavailability of heavy 
metals was greatest for $\mathrm{Zn}$ followed by $\mathrm{Pb}$ and $\mathrm{Cu}$. The general reduction in contamination with depth could be due to the anthropogenic origin of these trace metals.
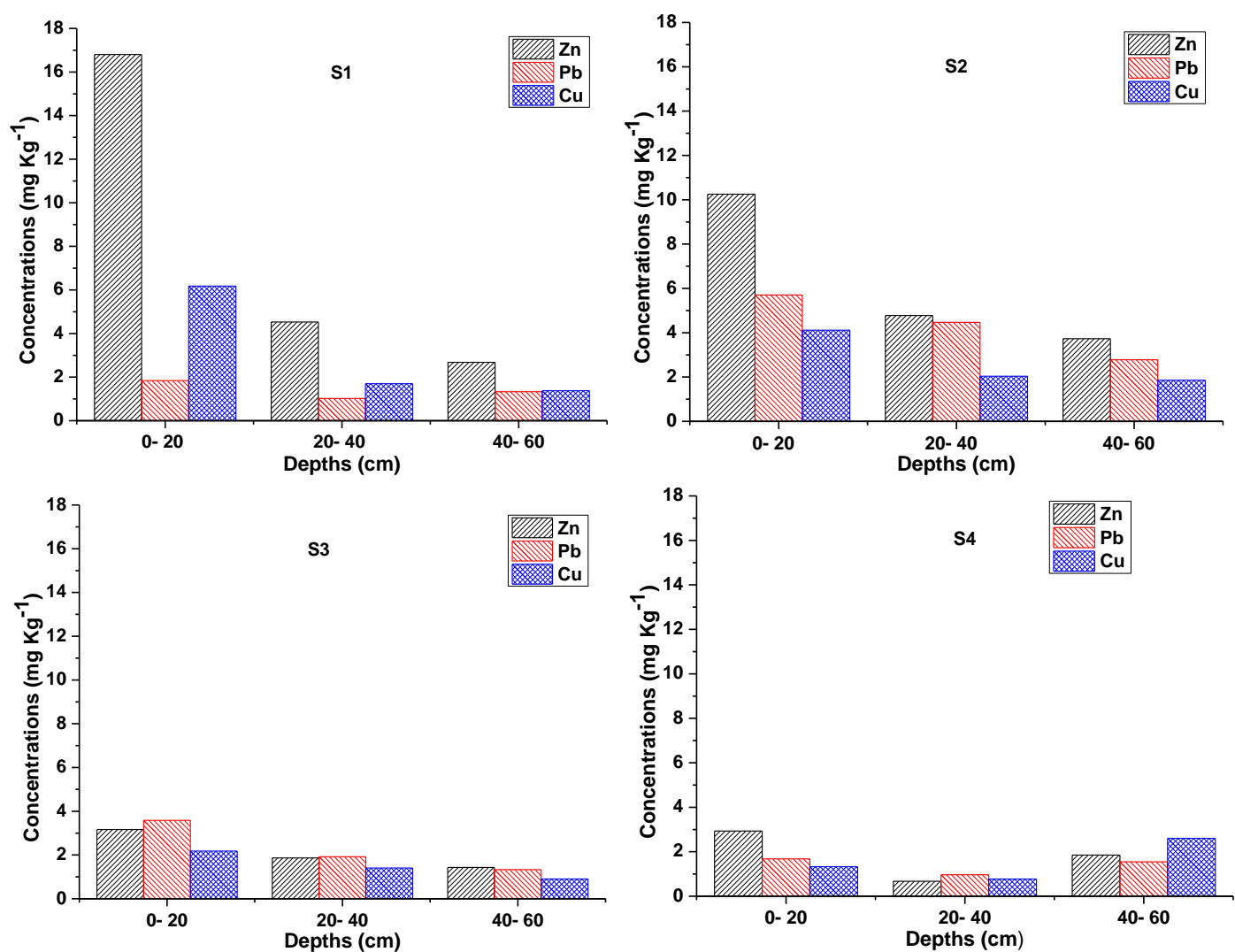

Figure 2. Concentrations of available trace metals ( $\mathrm{Zn}, \mathrm{Pb}$ and $\mathrm{Cu}$ ) extracted by the DTPA method for the four soil samples (S1, S2, S3 and S4) at three depths.

\section{Conclusions}

The modified BCR sequential extraction procedure was applied to soil collected around stocked solid waste 'a phosphogypsum' in Sfax (central eastern coast of Tunisia) to evaluate the mobility, bioavailability and potential toxicity of the heavy metal. The distribution of heavy metal in collected samples showed that the total concentrations were higher in the surface and the topsoil at site S1 than site S4. This amount decreased gradually with increasing distance from the dump of phosphogypsum and with increasing soil depth. The information obtained by sequential extraction procedure could be useful in developing effective management strategies to control metal pollution in study area. The fractionation studies indicated that mobile fractions of heavy metals were higher in the topsoil than in the deeper soil layers for most trace elements. Significant proportions of $\mathrm{Cu}, \mathrm{Cr}, \mathrm{Ni}$ and $\mathrm{Fe}$ at all three depths and of $\mathrm{Zn}$ at $40-60 \mathrm{~cm}$ were found in the residual fraction. The dominant proportions of $\mathrm{Zn}, \mathrm{Pb}$ and $\mathrm{Mn}$ were detected in the non-residual fraction. In fact, the proportion of $\mathrm{Zn}$ in the surface soil was in the following order: reducible $>$ residual $>$ exchangeable $>$ oxidizable (except at site S1, where exchangeable $>$ reducible $>$ residual $>$ oxidizable). Approximately $60 \%$ of the $\mathrm{Pb}$ was bound to the nonresidual (exchangeable and reducible) fraction at all sites and all soil depths (except for site S1, where most of the $\mathrm{Pb}$ was found in the residual fraction. The percentage of $\mathrm{Mn}$ in all soil samples was in the following order: exchangeable $>$ residual $>$ reducible $>$ oxidizable. The highest concentrations of DTPA extractable metals found in the topsoil at sites S1 and S2 indicate anthropogenic pollution and the potential accumulation of metals in vegetables. The ICF values of $\mathrm{Cu}, \mathrm{Cr}, \mathrm{Co}, \mathrm{Mn}$ and $\mathrm{Fe}$ followed the same order for the different layers of soil, as follows: $\mathrm{Pb}>\mathrm{Zn}>\mathrm{Mn}>\mathrm{Co}>\mathrm{Cu}>\mathrm{Cr}>\mathrm{Ni}>\mathrm{Fe}$. According to the computed individual contamination factors (ICF), the highest risk of $\mathrm{Zn}, \mathrm{Mn}$ and $\mathrm{Pb}$ was computed at sites $\mathrm{S} 1$ and $\mathrm{S} 2$. The global contamination factor (GCF) showed that the closest sites and topsoil from the dump of the phosphogypsum were highly impacted by metal pollutants, which can be explained by the tendency of trace metals to accumulate in surface soil. These findings indicate potential risks to public health.

\section{Acknowledgments}

This research was financially supported by the University of Sfax and the Minister of Research of Tunisia. Technical assistance was provided by the Laboratory of Soil Science in Gembloux, Belgium. The authors also thank all members and technicians of the Laboratory of Soil Science for their help with technical work. 


\section{References}

AFNOR (1996). Soil quality- Soils, sediments- Total solubilising by acid attack. NF X 31-147.

Aiju, L., Yanchun, G., Honghai, W., Gao Peiling, G. (2012) An Assessment of Heavy Metals Contamination in Xiaofu River Sediments through Chemical Speciation Study. International Journal of Earth Sciences 5(5): 1235-1240.

Bettinelli, M., Beone, G.M., Spezia, S., Baffi, C. (2000) Determination of heavy metals in soils and sediments by microwave-assisted digestion and inductively coupled plasma optical emission spectrometry analysis. Analytica Chimica Acta 424(2, 1): 289-296.

Bouguerra, S., Hentati, O., Marques, C.R., Sousa, J.P., Nogueira, V.I, Gomes, N.C., Mendo, S., Gonçalves, F., Ksibi, M., Römbke, J., Haddioui. A., Pereira, R. (2012) The impact of contamination by phophogypsum on the structural and functional diversity of the soil microbial community in a deposition area (Sfax, Tunisia). Poster WE 131 presented in SETAC Europe, $6^{\text {th }}$ SETAC World Congress, Berlin, Germany, 20-24 May 2012.

Bozkurt, S., Monero, L., Neretnieks, I. (2000) Long-term processes in waste deposits. Science of the Total Environment 250: 101-121. doi: http://dx.doi.org/ 10.1016/S0048-9697(00)00370-3.

Castillo-Carrion, M., Martin-Rubi, J.A., Bernaldo de Quiros, E.O. (2007) The distribution and fixation of trace elements by the Vertisols of Malaga, southern Spain. Science of the Total Environment 378: 28-35. doi: http://dx.doi.org/10.1016/j.scitotenv.2007.01.028.

Ciavatta, C., Vittori Antisari, L., Sequi, P. (1989) Determination of organic carbon in soils and fertilizers. Communications in Soil Science and Plant Analysis 20: 759-773. doi: http://dx.doi.org/10.1080/00103628909368115.

Vidal M, Rauret G. (1993) Community: The community Bureau of Reference (BCR). International Journal of Environmental Analytical Chemistry 51: 85. doi: http://dx.doi.org/10.1080/03067319308027613.

Covelo, E.F., Vega, F.A., Andrade, M.L. (2007) Simultaneous sorption and desorption of $\mathrm{Cd}, \mathrm{Cr}, \mathrm{Cu}, \mathrm{Ni}$, $\mathrm{Pb}$ and $\mathrm{Zn}$ in acid soils II: soil ranking and influence of soil characteristics. Journal of Hazardous and Materials 147: 862-870. doi: http://dx.doi.org/10.1016/j.jhazmat. 2007.01.108.

Cuong, D.T., Obbard, J.P. (2006) Metal speciation in coastal marine sediments from Singapore using a modified BCR-sequential extraction procedure. Applied Geochemistry 21: 1335-1346. doi: http://dx.doi.org/ 10.1016/j.apgeochem.2006.05.001.

Diaz-de Alba, M., Galindo-Riano, M.D., CasanuevaMarenco, M.J., Garcia-Vargas, M., Kosore, C.M. (2011) Assessment of the metal pollution, potential toxicity and speciation of sediment from Algeciras Bay (South of Spain) using chemometric tools. Journal of Hazardous Materials 190(1-3): 177-187. doi: http://dx.doi.org/ 10.1016/j.jhazmat.2011.03.020.

Davutluoglu, O.I., Seckin, G., Ersu, C.B., Yilmaz, T., Sari, B. (2011) Heavy metal content and distribution in surface sediments of the Seyhan River, Turkey. Journal of Environmental Management 92: 2250- 2259. doi: http://dx.doi.org/10.1016/j.jenvman.2011.04.013.

Davydova, S. (2005) Heavy metals as toxicants in big cities. Microchemie Journal 79(1-2): 133-136. doi: http://dx.doi.org/10.1016/j.microc.2004.06.010.

Favas Paulo, J.C., Pratas, J., Gomes, M., Elisa, P., Cala, V. (2011) Selective chemical extraction of heavy metals in tailings and soils contaminated by mining activity: Environmental implications. Journal of Geochemical
Exploration 111: 160-171. doi: http://dx.doi.org/ 10.1016/j.gexplo.2011.04.009.

García-Delgado, C., Cala, V., Eymar, E. (2012) Influence of chemical and mineralogical properties of organic amendments on the selection of an adequate analytical procedure for trace elements determination. Talanta 88(15): 375-84. doi: http://dx.doi.org/10.1016/ j.talanta.2011.11.003.

Gasparatos, D., Papafilippaki, A., Haidouti, C., Massas, I. (2001) Evaluation of $\mathrm{Pb} \mathrm{Cu}$ and $\mathrm{Zn}$ bioavailability in contaminated soils from an urban - industrial area in Greece. In: XXXI Annual ESNA Meeting, Chania, Greece, pp. 52 -56.

Ghaderi, A.A., Abduli, M.A., Karbassi, A.R., Nasrabadi, T., Khajeh, M. (2012) Evaluating the Effects of Fertilizers on Bioavailable Metallic Pollution of soils, Case study of Sistan farms, Iran. International Journal of Environmental Research 6(2): 565-570.

Horckmans, L., Swennen, R., Deckers, J. (2007) Retention and release of $\mathrm{Zn}$ and $\mathrm{Cd}$ in spodic horizons as determined by $\mathrm{pH}(\mathrm{stat})$ analysis and single extractions. Science of the Total Environment 376(1-3): 86-99. doi: http://dx.doi.org/10.1016/j.scitotenv.2007.01.077.

Hursthouse, A.S. (2001) The relevance of speciation in the remediation of soil and sediments contaminated by metallic elements - an overview and examples from central Scotland, UK. Journal of Environmental Monitoring 3: 49-60. doi: http://dx.doi.org/10.1039/ b006132h.

ISO 23470 (2007). Soil quality - determination of effective cation exchange capacity (CEC).

Issaron, N., Abil-Ghanem, C., Bermond A. (2009) Fractionation studies of mercury in soils and sediments: a review of the chemical reagents used for mercury extraction. Analytica Chimica Acta 631: 1-12. doi: http://dx.doi.org/10.1016/j.aca.2008.10.020.

Jamali, M.K., Kazi, T.G., Afridi, H.I., Arain, M.B., Jalbani, N., Memon, A.R. (2007) Speciation of heavy metals in untreated domestic wastewater sludge by time saving BCR sequential extraction method. Journal of Environmental Science and Health Part A, 42: 649-659. doi: http://dx.doi.org/10.1080/10934520701244433.

Kierczak, J., Neel, C., Aleksander-Kwaterczak, U., HeliosRybicka, E., Bril, H., Puziewicz, J. (2008) Solid speciation and mobility of potentially toxic elements from natural and contaminated soils: A combined approach. Chemosphere 73: 776-784. doi: http://dx.doi.org/10.1016/j.chemosphere.2008.06.015.

Lee, C.S.L., Li, X.D., Zhang, G., Li, J., Ding, A.J., Wang, T. (2007) Heavy metals and $\mathrm{Pb}$ isotopic composition of aerosols in urban and suburban areas of Hong Kong and Guangzhou, South China - Evidence of the Long-range Transport of Air Contaminants. Atmospheric Environment 41: 432-447. doi: http://dx.doi.org/ 10.1016/j.atmosenv.2006.07.035.

Luo, X., Yu, S., Li, X. (2012) The mobility, bioavailability, and human bioaccessibility of trace metals in urban soils of Hong Kong. Applied Geochemistry 27: 995-1004. doi: http://dx.doi.org/10.1016/j.apgeochem.2011.07. 001

Maas, S., Scheifler, R., Benslama, M., Crini, N., Lucot, E., Brahmia, Z., Benyacoub, S., Giraudoux, P. (2010) Spatial distribution of heavy metal concentrations in urban, suburban and agricultural soils in a Mediterranean city of Algeria. Environmental Pollution 158: 2294-2301. doi: http://dx.doi.org/10.1016/ j.envpol.2010.02.001.

Maiz. I., Arambarri, I., Garcia, R., Mill`an, E. (2000) Evaluation of heavy metal availability in polluted soils by two sequential extraction procedures using factor 
analysis. Environmental Pollution 110: 3-9. doi: http://dx.doi.org/10.1016/S0269-7491(99)00287-0.

Marques, C. R., Caetano, A. L., Haller, A., Gonc, Alves, F., Pereira, R., Römbked, J. (2014) Toxicity screening of soils from different mine areas-A contributionto track the sensitivity and variability of Arthrobacter globiformis assay. Journal of Hazardous Materials 274: 331-341. doi: http://dx.doi.org/10.1016/j.jhazmat.2014. 03.066.

Martin, R., Sanchez, D.M., Gutierrez, A.M. (1999) Sequential extraction of U,Th, Ce, La, and some heavy metals in sediments from Ortigas Revier, Spain. Talanta 46: 1115-1121. doi: http://dx.doi.org/ 10.1016/S0039-9140(97)00374-3.

Morillo, J., Usero, J., Gracia, I. (2007) Potential mobility of metals in polluted coastal sediments in two bays of southern Spain. Journal of Coastal Research 23: 352361. doi: http://dx.doi.org/10.2112/04-0246.1.

Nafeh Kassir, L., Darwish, T., Shaban, A., Olivier, G., Naim, O. (2012) Mobility and bioavailability of selected trace elements in Mediterranean red soil amended with phosphate fertilizers: Experimental study. Geoderma 189-190: 357-368. doi: http://dx.doi.org/10.1016/ j.geoderma.2012.05.017.

Naji, A., Ismail, A., Ismail, A.R. (2010) Chemical speciation and contamination assessment of $\mathrm{Zn}$ and $\mathrm{Cd}$ by sequential extraction in surface sediment of Klang River, Malaysia. Microchem. J. 95: 285-292. doi: http://dx.doi.org/10.1016/j.microc.2009.12.015.

Naji, A., Ismail, A.R. (2011) Spatial Variation and Binding Behavior of $\mathrm{Cu}$ and $\mathrm{Pb}$ in Surface Sediments of Klang River. International Journal of Chemical Engineering 2(2).

Nemati K, Abu Bakar N.K., Radzi Abas M, Sobhanzadeh E. (2011) Speciation of heavy metals by modified BCR sequential extraction procedure in different depths of sediments from Sungai Buloh, Selangor, Malaysia. Journal of Hazardous Materials, 192(1): 402-410.

Papafilippaki, A., Velegraki, D., Vlachaki, C., Stavroulakis, G. (2008). Levels of heavy metals and bioavailability in soils from the industrial area of Heraklion-Crete, Greece. Protection and Restoration of the Environment IX Kefalonia.

Perez-Lopez, R., Nieto, J.M., Lopez-Coto, I., Aguado, J.L., Bolivar, J.P., Santisteban, M. (2010) Dynamics of contaminants in phosphogypsum of the fertilizer industry of Huelva (SW Spain): From phosphate rock ore to the environment. Applied Geochemistry 25: 705715. doi: http://dx.doi.org/10.1016/j.apgeochem.2010. 02.003.

Prasad, M.N.V. (2008). Trace Elements as Contaminants and Nutrients: Consequences in Ecosystems and Human Health, pp. 777, USA: John Wiley \& Sons. doi: http://dx.doi.org/10.1002/9780470370124.

Pueyo, M., Mateu, J., Rigol, A., Vidal, M., Lo'pezSa'nchez, J.F., Rauret, G. (2008) Use of the modified BCR three-step sequential extraction procedure for the study of trace element dynamics in contaminated soils. Environmental Pollution 152: 330-341. doi: http://dx.doi.org/10.1016/j.envpol.2007.06.020.

Rao, C.R.M., Sahuquillo, A., Lopez-Sanchez, J.F. (2010) Comparison of single and sequential extraction procedures for the study of rare earth elements remobilisation in different types of soils. Analytica Chimica Acta 662(2): 128-136. doi: http://dx.doi.org/10.1016/j.aca.2010.01.006.

Rauret, G., Lopez-Sanchez, J.F., Sahuquillo, A., Rubio, R., Davidson, C., Ure, A., Quevauviller, P. (1999) Improvement of the $\mathrm{BCR}$ three step sequential extraction procedure prior to the certification of new sediment and soil reference materials. Journal of Environmental Monitoring 1: 57-61. doi: http://dx.doi.org/10.1039/a807854h.

Rayment, G.E., Higginson, F.R. (2002). Australian Handbook of Soil and Water Chemical Methods. Melbourne, Australia: Inkata Press.

Raži'c, S., Dogo, S. (2010) Determination of chromium in Mentha piperita L. and soil by graphite furnace atomic absorption spectrometry after sequential extraction and microwave-assisted acid digestion to assess potential bioavailability. Chemosphere 78(4): 451-456. doi: http://dx.doi.org/10.1016/j.chemosphere.2009.10.028.

Richards, L.A., ed. Diagnosis and improvement of saline and alkali soils (pp. 57-63). USDA Agriculture Handbook No. 60. Washington D.C.: United States Salinity Laboratory Staff,, 1954.

Saracoglu, S., Soylak, M., Elci, L. (2009) Extractable trace metals contents of dusts of air filters from vehicles by sequential extraction procedure. Journal of the Association of Official Agricultural Chemists 92: 11961202.

Sun, L., Chen, S., Chhao, L., Sun, T. (2007) Effects of flooding on changes in $\mathrm{Eh}, \mathrm{pH}$ and speciation of cadmium and Lead in contaminated Soil. The Bulletin of Environmental Contamination and Toxicology 79: 514518. doi: http://dx.doi.org/10.1007/s00128-007-9274-8.

Szynkowska, M.I., Pawlaczyk, A., Leśniewska, E., Paryjczak, T. (2009) Toxic Metal Distribution in Rural and Urban Soil Samples Affected by Industry and Traffic. Polish Journal of Environmental Studies 18(6): 1141-1150.

Tessier, A., Campbell, P.G.C., Bisson, M. (1979) Sequential extraction procedure for the speciation of particulate trace metals. Journal of Analytical Chemistry 51(7): 844- 851. doi: http://dx.doi.org/10.1021/ac50043a017.

Umoren, I.U., Udoh, A.P., Udousoro, I.I. (2007) Concentration and chemical speciation for the determination of $\mathrm{Cu}, \mathrm{Zn}, \mathrm{Ni}, \mathrm{Pb}$ and $\mathrm{Cd}$ from refuse dump soils using the optimized BCR sequential extraction procedure. Environmentalist 27: 241-252. doi: http://dx.doi.org/10.1007/s10669-007-9001-3.

Vandecasteele, B., De Vos, B., Tack, F.M.G. (2003) Temporal-spatial trends in heavy metal contents in sediment-derived soils along the Sea Scheldt river (Belgium). Environnemental Pollution 122(1): 7-18. doi: http://dx.doi.org/10.1016/S0269-7491(02)00282-8.

Vega, F.A., Covelo, E.F., Andrade, M.L., Marcet. P. (2004) Relationship between heavy metals content and soil properties in mine soils. Analytical Chemical Acta 524: 141-150. doi: http://dx.doi.org/10.1016/j.aca.2004.06. 073.

Wali, A., Coinet, G., Khadhraoui, M., Ksibi, M. (2013) Trace metals in surface soil contamination by release of Phosphate industry in the surroundings of Sfax-Tunisia. Environmental Research, Engineering and Management 65(3): 20-30.

Yang, Y., Chen, F., Zhang, L., Liua, J., Wu, S., Kang, M. (2012) Comprehensive assessment of heavy metal contamination in sediment of the Pearl River Estuary and adjacent shelf. Marine Pollution Bulletin 64: 19471955. doi: http://dx.doi.org/10.1016/j.marpolbul. 2012.04.024.

Yang, Z., Wang, Y., Shen, Z., Niu, J., Tang, Z. (2009) Distribution and speciation of heavy metals in sediments from the main stream, tributaries, and lakes of the Yangtze river catchment of Wuhan, China. Journal of Hazardous Materials 166: 1186-1194. doi: http://dx.doi.org/10.1016/j.jhazmat.2008.12.034.

Yap, C.K., Choh, M.S., Edward, F.B., Ismail. A., Tan, S.G. (2006) Comparison of heavy metal concentrations in 
surface sediment of Tajung Piai wetland with other sites receiving anthropogenic inputs along the southwestern coast of Peninsular Malaysia. Wetland Science 4(1): 4857.

Yu, X.J., Yan, Y., Wang, W.X. (2010) The distribution and speciation of trace metals in surface sediments from the Pearl River Estuary and the Daya Bay, Southern China. Marine Pollution Bulletin 60: 1364-1371. doi: http://dx.doi.org/10.1016/j.marpolbul.2010.05.012.

Yuan, C., Shi, J., He, B., Liu, J., Liang, L., Jiang, G. (2004) Speciation of heavy metals in marine sediments from the East China Sea by ICP-MS with sequential extraction. Environment International 30: 769-783. doi: http://dx.doi.org/10.1016/j.envint.2004.01.001.

Zemberyova, M., Bartekova, J., Hagarova, I. (2006) The utilization of modified BCR three-step sequential extraction procedure for the fractionation of $\mathrm{Cd}, \mathrm{Cr}, \mathrm{Cu}$, $\mathrm{Ni}, \mathrm{Pb}$ and $\mathrm{Zn}$ in soil reference materials of different origins. Talanta 70: 973-978. doi: http://dx.doi.org/ 10.1016/j.talanta.2006.05.057. 


\title{
Sunkiųjų metalų atmainų nustatymas modifikuotu BCR nuoseklaus išgavimo metodu fosfogipsu užterštame dirvožemyje Sfakse, Tunise
}

\author{
Ahmed Wali ${ }^{1}$, Gilles Colinet ${ }^{2}$, Mohamed Ksibi ${ }^{1}$

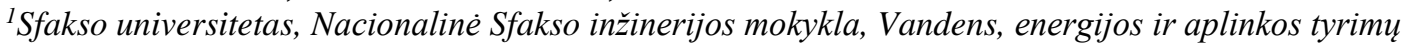 \\ laboratorija, Sfaksas, Tunisas \\ ${ }^{2}$ Dirvotyros laboratorija, Žanblu agrobiotechnologijos fakultetas, Lježo universitetas, Žanblu, Belgija
}

Metalų kaupimasis dirvožemyje yra opi aplinkos apsaugos problema, dėl jos kyla metalų patekimo ị vandenị arba augalus pavojus. Siekiant suprasti metalų judumą ir biologinị ịsisavinimą, skirtingoms fizinèms ir cheminėms dirvožemio fazèms turi būti nustatyta metalų pẻdsakų koncentracija ir pasiskirstymas. Bendrijos etalonų biuro (Community Bureau of Reference) rekomenduotu nuoseklaus išgavimo metodu buvo nustatytos šių metalų: $\mathrm{Zn}, \mathrm{Pb}, \mathrm{Cu}, \mathrm{Cr}, \mathrm{Co}, \mathrm{Ni}$, $\mathrm{Mn}$ ir Fe - koncentracijos dirvožemyje reikšmės ir ištirtos tokios cheminės dirvožemio savybės, kaip pH, katijonų mainų talpa, suminis organinès anglies kiekis, elektrinis laidumas ir kalcio karbonato kiekis. Rezultatai parodè, kad daugumos metalų koncentracijos reikšmès viršutinio dirvožemio sluoksnio $(0-20 \mathrm{~cm})$ mėginiuose buvo didesnès negu podirvio $(20-40 \mathrm{~cm}$ ir $40-60 \mathrm{~cm})$ mėginiuose visose keturiose tyrimo vietose. Visose tyrimo vietose viršutiniame dirvožemio sluoksnyje esantis Zn daugiausia buvo siejamas su neatsparia frakcija. Visose tyrimo vietose ir dirvožemio gyliuose apie $60 \%$ daugiau Pb buvo dèl neišliekamųjų, judriųjų ir mažejančių frakcijų. Daugiausia $\mathrm{Cr}, \mathrm{Cu}$, Ni ir Fe buvo liekamojoje frakcijoje, o Mn - neatsparioje frakcijoje. Bendras užterštumo metalais koeficientas mažèjo didèjant dirvožemio gyliui. Didžiausias judrumas ir biologinis įsisavinimas buvo nustatytas $\mathrm{Zn}$, po to $\mathrm{Cu}$ ir $\mathrm{Pb}$.

Raktiniai žodžiai: nuoseklus išgavimas, judumas, mikroelementai, dirvožemis, rizikos vertinimas. 